\title{
A CASE REPORT OF ENORMOUS FIBROID-POLYP
}

\author{
Hrishikesh Madanlal Mandhane' ${ }^{1}$, Aher G. S2 ${ }^{2}$ Urmila Gavli ${ }^{3}$
}

\section{HOW TO CITE THIS ARTICLE:}

Hrishikesh Madanlal Mandhane, Aher G. S, Urmila Gavli. "A Case Report of Enormous Fibroid-Polyp". Journal of Evolution of Medical and Dental Sciences 2015; Vol. 4, Issue 32, April 20; Page: 5606-5608,

DOI: $10.14260 /$ jemds/2015/821

ABSTRACT: INTRODUCTION: Huge cervical polyp causing diagnostic dilemma is rarely encountered in gynecologic practice. The objective of this study is to document a case of huge cervical polyp masquerading as cervical cancer seen and managed at PDVVPF's Medical College \& hosp, Ahmednagar. CONCLUSION: Although giant cervical fibroid is rare, it may masquerade as cervical malignancy or uterine inversion. Proper evaluation is needed to make an accurate diagnosis.

KEYWORDS: Cervical fibroid-polyp, Abdomino-Vaginal approach.

INTRODUCTION: Leiomyoma is the commonest of all uterine and pelvic tumours, with an incidence of almost $20 \%$ in women of reproductive age group. Most leiomyomas are situated in the body of uterus but in $1-2 \%$ of cases they are confined to cervix. ${ }^{1}$ cervical leiomyoma is commonly single and is either interstitial or sub serous. Rarely does it become submucous or polypoidal. Huge cervical fibroid-polyp causing diagnostic dilemma is rarely encountered in gynecological practice. Only handful of cases have been reported in the literature. ${ }^{2}$ The objective of this case report is to document a huge cervical fibroid-polyp masquerading as cervical cancer \& managed at PDVVPF's Medical College \& hosp., Ahmednagar.

CASE REPORT: A 45 year multiparous not living with husband, presented with fullness of vagina, mass coming out of introitus since 18 months, foul smelling discharge and on and off per-vaginal bleeding since 1 year and difficulty in walking. Past menstrual history revealed normal cycles. Patient's general and systemic examination was normal except for severe pallor. Abdominal examination revealed no abnormality. On local examination large irregular mass about 20x10x7cm seen outside the introitus covered with infected shaggy dirty white membrane that bleeds on touch. Per-speculum examination was difficult due to huge mass. On Bimanual examination: Uterus was bulky about 6 to 8 weeks gestational size and mass was coming through cervix. Per rectal examination: rectal mucosa and parametrium free. Differential diagnosis of fibroid-polyp, ca cervix, fibrosarcoma was considered. Pap smear and cervical biopsy showed only inflammatory changes with no evidence of malingnancy.

After 2 blood transfusion and control of local infection with systemic antibiotic, patient was taken for Abdominal Hysterectomy. Routine abdominal hysterectomy was proceeded upto Mackenrodt's and uterosacral ligaments, and specimen was delivered vaginally and hysterectomy completed. The mass weighed $1.2 \mathrm{~kg}$. Post-operative recovery was uneventful histopathological report- confirmed Fibroid-polyp.

DISCUSSION: The present case was the only case of giant cervical polyp in our center over last 9 years, thus reaffirming its rarity observed by previous workers.3,4 Massinde co-workers from Tanzania reported a case of large cervical polyp with uterine prolapse in a 55 years old multiparous 
woman. Khalid and Colleagues from lebenon reported a case of giant cervical polyp in a sexually inactive nulliparous lady. Amesse and Colleagues reported a case of huge cervical polyp in adolescence.

Most of the reported cases of giant or huge cervical polyp were found in perimenopausal women like ours. The symptom complex presented by patient-huge mass coming out per vaginum associated with vaginal bleeding \& discharge was consistent with established data \& mimicked cervical malignancy, thus emphasizing the importance of Histological examination particularly in environment where cervical carcinoma is common (like ours). $5,6,7,8$ However it is documented that only about $2 \%$ of cervical polyp undergo malignant transformation, but it cannot be overlooked. 7,8

The treatment for cervical polyp is Polypectomy, however in our case it was combined with total abdominal hysterectomy as patient had completed family size.

Fig. 1: Large irregular mass covered with infected shaggy dirty white membrane that bleeds on touch.

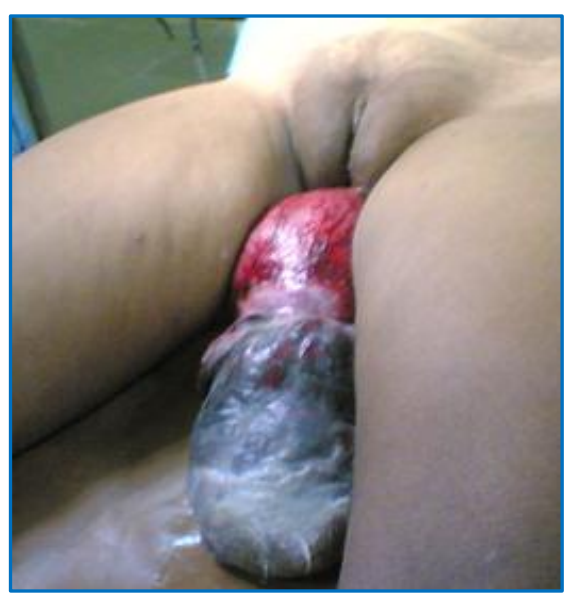

Fig. 1

Fig. 2: Specimen showing uterus with cervix and large fibroid-polyp.

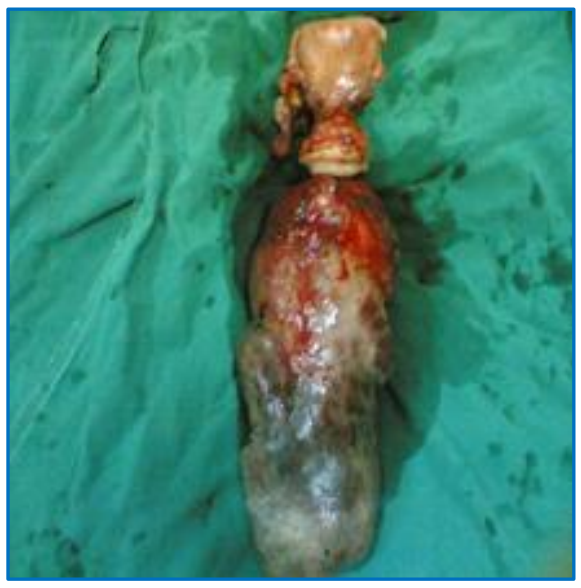

Fig. 2 
CONCLUSION: Although giant cervical fibroid-polyp is rare, it may masquerade cervical malignancy or uterine inversion and proper evaluation is needed to make an accurate diagnosis. In case of cervical fibroid or submucosal, pedunculated fibroid-polyp, it is imperative to have thorough preoperative evaluation, anticipate operative challenges and strike a judicious and rational approach about deciding the route of hysterectomy. Large central cervical fibroid-polyp is very difficult to handle and needs an expert hand to operate as in the present case.

\section{REFERENCES:}

1. Bhatla N Tumous of the corpus uteri. In: Jeff Coates principles of Gynaecolgy $5^{\text {th }}$ edition London, Arnold Publisher. 2001; 407.

2. Bucello D, Frederic B, Noel JC. Giant cervical polyp: A case report and review of rare entity. Arch Gynecol Obstet 2008; 278: 2-8.

3. Massinde AN, Mpogoro F, Rumanyika RN, Magona M.Uterine prolapsed complicated with giant cervical polyp. J Low Genit Tract Dis 2012; 16: 64-5.

4. Amesse LS, Taneja A, Broxson E, Pfaff-Amesse J. Protruding giant cervical polyp in a young adolescent with a previous rhadomyosarcoma. J Pediatr Adolesc Gynecol 2002; 15: 271-7.

5. Khalil AM, Azar GB, Kasoar HG, Abu-Musa AA, Charara IR, Seoud MA. Giant cervical polyp: A case report. J Repod Med 1996; 41: 619-21.

6. Yi KW, Song SH, Kim KA, Jung WY, Lee JK, Hur JY. Giant endocervical polyp mimicking cervical malignancy: Primary excision and hysteroscopic resection. J Minim Invasive Gynecol 2009; 16: 498-500.

7. Duckman S, Suarez JR, Sese LQ. Giant cervical polyp. Am J Obstet Gynecol 1988; 159: 852-4.

8. Abdul MA, Koledade AK, Madugu N. Giant cervical polyp complicating uterine fibroid and masquerading as cervical malignancy. Arch Int Surg 2012; 2: 39-41.

\section{AUTHORS:}

1. Hrishikesh Madanlal Mandhane

2. Aher G. S.

3. Urmila Gavli

\section{PARTICULARS OF CONTRIBUTORS:}

1. Senior Resident, Department of Obstetrics \& Gynaecology, Padmashree Dr. Vithalrao Vikhe Patil Medical College \& Hospital.

2. Professor, Department of Obstetrics \& Gynaecology, Padmashree Dr. Vithalrao Vikhe Patil Medical College \& Hospital.
3. Assistant Professor, Department of Obstetrics \& Gynaecology, Padmashree Dr. Vithalrao Vikhe Patil Medical College \& Hospital.

\section{NAME ADDRESS EMAIL ID OF THE} CORRESPONDING AUTHOR:

Dr. Hrishikesh Madanlal Mandhane, Mandhane Hospital, Court Road, Paithan, Aurangabad- 431107.

E-mail: hrishmmandhane@gmail.com

Date of Submission: 22/01/2015. Date of Peer Review: 23/01/2015. Date of Acceptance: 08/04/2015. Date of Publishing: 20/04/2015. 